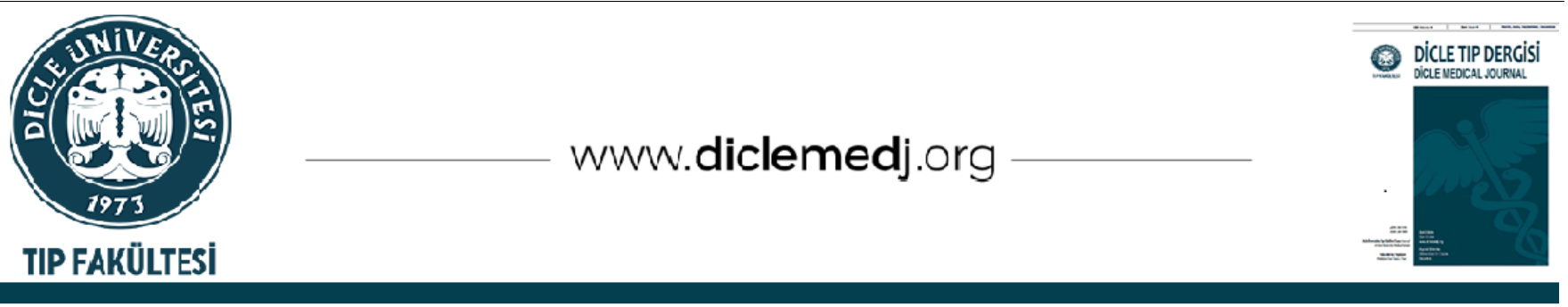

Original Article / Özgün Araştırma

\title{
What Do Medical Students Think About HIV/AIDS? Student thoughts on HIV / AIDS
}

\author{
Fatma Kesmez Can ${ }^{1}$, Handan Alay ${ }_{1}$ \\ 1 Department of Infectious Diseases and Clinical Microbiology, Atatürk University School of Medicine, Erzurum, Turkey
}

Received: 18.03.2021; Revised: 17.05.2021; Accepted: 18.05.2021

\begin{abstract}
Objective: With this study, we wanted to reduce the transmission of HIV/AIDS and to improve the attitudes and behaviors of physician candidates towards HIV/AIDS patients. For this reason, we first measured the knowledge levels of the students. Raising awareness of doctor candidates is a strategic move to protect against HIV / AIDS and to make these patients benefit from health services without any problem.
\end{abstract}

Methods: Using a questionnaire, we measured HIV/AIDS knowledge levels of students (960) who were continuing their education in the medical school of Atatürk University. The questionnaire consisted of five parts: demographic characteristics, general information, ways of transmission, ways of protection, attitudes, and behaviors. Ethics committee permission was obtained for the study and the survey data were analyzed in SPSS 20 package program.

Results: We noticed that physician candidates, especially ethical issues, were confused in some questions. The results were not enough for medical school. 960 volunteers participated in the study, of which 532 (55.4\%) were women and 428 (44.6\%) were men. The students knew that an HIV carrier and a patient diagnosed with AIDS are different from each other (78.2\%). They said that HIV is a virus that weakens the immune system (86\%) and AIDS has no radical treatment (97.4\%). However, students' answers about pregnant women and nursing mothers were discrepancy.

Conclusion: We saw that young people need education on HIV/AIDS. For this reason, a training seminar was given by the academicians at Atatürk University on World AIDS Day. The students who participated in our study and education stated that they were not afraid of the patients with AIDS and learned the subject. We expect that this training will improve the approach of doctor candidates to the patient and that the provision of training in all faculties will reduce the increase in HIV / AIDS.

Keywords: HIV/AIDS, Students, Education, Medical Faculty, Turkey

\section{DOI: 10.5798/dicletip.944326}

Correspondence / Yazışma Adresi: Fatma Kesmez Can, Department of Infectious Diseases and Clinical Microbiology, Atatürk University School of Medicine, Erzurum, Turkey e-mail: fatma.can@atauni.edu.tr 


\section{Tıp Öğrencileri HIV/AIDS Hakkında Ne Düşünüyor? HIV/AIDS İle İlgili Öğrenci Düşünceleri}

Öz

Amaç: Bu çalışma ile HIV/AIDS bulaşını azaltmak ve hekim adaylarının HIV/AIDS hastalarına yönelik tutum ve davranışlarını iyileștirmek istedik. Bu nedenle öncelikle öğrencilerin bilgi düzeylerini ölçtük. Doktor adaylarının bilinçlendirilmesi, HIV/AIDS'den korunmak ve bu hastaların sağlı hizmetlerinden sorunsuz bir şekilde yararlanmasını sağlamak için stratejik bir harekettir.

Yöntemler: Atatürk Üniversitesi Tıp Fakültesi'nde eğitimine devam eden öğrencilerin (960) HIV/AIDS bilgi düzeylerini anket aracilığıyla ölçtük. Anket beş bölümden oluşuyordu: demografik özellikler, genel bilgiler, bulaşma yolları, korunma yolları, tutumlar ve davranışlar. Çalışma için etik kurul izni alınmış ve anket verileri SPSS 20 paket programında analiz edilmiştir.

Bulgular: Başta etik konular olmak üzere hekim adaylarının bazı sorularda kafalarının karıștığını fark ettik. Tıp fakültesi için sonuçlar yeterli değildi. Çalışmaya 532'si (\% 55,4) kadın, 428'i (\% 44,6) erkek olmak üzere 960 gönüllü katıldı. Öğrenciler, HIV taşıyıcısı ile AIDS tanısı almıș bir hastanın birbirinden farklı olduğunu biliyordu (\% 78,2). HIV'in bağışıklık sistemini zayıflatan bir virüs olduğunu (\% 86) ve AIDS'in radikal tedavisi olmadığını $(\% 97,4)$ söylediler. Ancak öğrencilerin hamile kadınlar ve emziren anneler hakkındaki cevapları tutarsızdı.

Sonuç: Gençlerin HIV/AIDS konusunda eğitime ihtiyacı olduğunu gördük. Bu nedenle Atatürk Üniversitesi akademisyenleri tarafından Dünya AIDS Günü ile ilgili eğitim semineri verildi. Çalışmamıza ve eğitimimize katılan öğrenciler, AIDS'li hastalardan korkmadıklarını belirterek konuyu öğrendiler. Bu eğitimin doktor adaylarının hastaya yaklaşımını geliştireceğini ve tüm fakültelerde eğitim verilmesinin HIV/AIDS artışını azaltacağını umuyoruz.

Anahtar kelimeler: HIV / AIDS, Öğrenciler, Eğitim, Tıp Fakültesi, Türkiye.

\section{INTRODUCTION}

HIV (Human immunodeficiency virus) in the Retroviridae family is a lentivirus with double polarity RNA ${ }^{1,2}$. AIDS (Acquired Immune Deficiency Syndrome) is a human immune system disease caused by HIV3. AIDS disrupts the function of immune system cells, which is a duty of preventing infections, this results in immunosuppression leading to opportunistic infections and associated complications ${ }^{4,5}$.

HIV / AIDS is one of the most important pandemics in the world with increasing number of cases. The global HIV/AIDS pandemic has so far caused the deaths of 39 million people and today approximately 36.9 million people live with HIV 6 . The first time in the United States in the early 1980s at homosexual men and drug addicts, opportunistic infections were observed such as Kaposi's sarcoma and Pneumocystis jirovecii pneumonia, it was noticed to be a new disease with immunodeficiency. In 1982, a case definition was made by the US Center for
Disease Control and Prevention using the concept of AIDS for the first time 7 . In Turkey, the first HIV-positive case was reported in 1985 and in later years the number has increased. T. C. According to the Ministry of Health in Turkey until the date of December 31, 201514695 HIV cases have been reported, 1537 of them are AIDS $^{8,9}$. In 1985 for the prevention of HIV transmission by blood transfusion has been made mandatory screening of all blood and blood products for HIV. In Turkey, this practice has been in effect since $1987^{10}$. But the WHO official site, it does not have data, Turkey.

For HIV / AIDS infection, direct contact of body fluids (blood and blood products, sperm, other genital secretions, milk and placenta) is required $^{7,11}$. Apart from this, contaminated tools which break the skin integrity (razor blades, injectors, tattoo needles, body piercing and other similar tools etc.) are a separate way of transmission. The risk of vascular transmission with developing measures is now a risk factor for substance addicts who only 
receive intravenous substance. Although there is a high risk of exposure to blood and body fluids, HIV transmission has been reported to be rare due to exposure of health personnel to contaminated needles or body fluids. In HIVinfected mothers, there are cases of virus transmission with placenta or milk to the baby. Thanks to the studies and methods developed in this respect, it is now possible to prevent HIV transmission from mother to baby ${ }^{12}$. Approximately 4-6 weeks after contact with HIV, HIV antibodies become detectable. Infected individuals undergo seroconverting for 3 months and they are positive for the HIV antibody; rarely, this period can last up to 6 months ${ }^{11}$. Despite the prejudices of society, a handshake, a hug, sit in the same place; share the same bathroom, sauna, pool, toilet; use the same plate, Cup, fork, spoon; wear the same clothes; phone headset; tears, sweat, saliva; the mosquitoes, insects and bee stings do not cause HIV transmission8. In the worldwide $51 \%$ of the HIV-infected population are women, and $78 \%$ of the infected individuals are 25 years of age or older $^{13}$. According to the World Health Organization and the Joint United Nations Program on HIV / AIDS; young people are more susceptible to HIV infection because they lack health information and do not apply to health facilities due to social pressure after risky behaviors ${ }^{14}$. Informing the young people of the society about HIV / AIDS constitutes the most important step to reduce the risk of transmission. In addition, candidates who will provide health services should not be biased or stigmatizing, patient information should not be shared, and they should not ignore ethical responsibilities. It is also important that they be adequately informed in order not to be shy about approaching HIV-infected individuals or patients with AIDS and not to behave like fear, anxiety and unwillingness in interventions ${ }^{15}$.

In many studies, it was reported that the knowledge level of HIV / AIDS transmission in the first four years of the Faculty of Medicine students was insufficient. In addition, it has been proven by studies that information and awareness raising activities are effective in preventing HIV / AIDS among young people ${ }^{16}$. In this study, we aimed to determine the levels of HIV / AIDS knowledge by applying a questionnaire to the students of the medical faculty of Atatürk University and to inform the students by raising awareness about the subject.

\section{METHODS}

\section{Sample and Setting}

In the 2018-2019 academic year, a total of 1718 students are continuing Atatürk University Medical Faculty. The sixth grades were excluded from the study population and a questionnaire was applied to all medical faculty students who voluntarily responded to the questionnaire. In the curriculum of Atatürk University Faculty of Medicine, there is no direct HIV / AIDS training except for clinical training. However, HIV / AIDS is also described in the sexually transmitted diseases lesson. This subject is 2 hours and the first year.

\section{Data Collection}

The literature review was conducted and the questionnaire prepared by the researchers was applied to the volunteer students after giving verbal information about the research. The survey consists of five chapters. The first section questions the age, gender and educational level of the students. The second part includes questions about the level of general knowledge about HIV / AIDS, the third section transmission paths, and the fourth section the level of knowledge about prevention. The fifth section aims to determine the attitudes and behaviors of students about HIV / AIDS2,12.

The study initiation, ethical approval was obtained from the ethical board of the university where the study was conducted. The research protocol was approved by the Atatürk 
University Medical Faculty research ethics committee before the study (Ethics Committee Approval Number: B.30.2.ATA.0.01.00/314). Students were verbally informed about the aim of study and were told that their personal data would not be disclosed. In addition, permission was obtained from the Atatürk University medical faculty management to conduct a survey for students.

\section{Data Analysis}

The data were evaluated with SPSS 20 package program. In the analysis, the average number of correct answers and the classes of the students were compared. $\mathrm{p}<0.05$ was accepted as a significant difference limit in the statistical level.

\section{RESULTS}

960 volunteers participated in the study, of which 532 (55.4\%) were women and 428 $(44.6 \%)$ were men. The average age is $20 \pm 1$ year (table I). When the answers of the doctor candidates to the questionnaire were examined, the results were promising. The students knew that an HIV carrier and a patient diagnosed with AIDS are different from each other (78.2\%). They knew that HIV was a viral agent (90.2\%). They said that HIV is a virus that weakens the immune system (86\%) and AIDS has no radical treatment (97.4\%). In questions about the transmission of HIV, the students said that there could be sexual transmission (85.9\%), it could be in situations such as uncontrolled blood transfusions (96.3\%), contaminated needle sticks (73.2\%), however, there would be no transmission such as shaking hands or using the same glass $(85.5 \%)$. In the section on ways of transmission, students gave conflicting answers about questions about pregnant women and nursing mothers and about ways of sexual transmission. These questions were examined in the discussion section. In the section containing questions about ways to protect, candidates for physicians knew that healthcare workers were at high risk (87\%) and that protective equipment was important (95.1\%). But they didn't have enough answers about how to protect them from sexually transmitted. Finally, we have reached quite variable answers in questions involving ethics and physician initiative. There are unanswered issues around the world about HIV / AIDS patients and healthy people's rights in conflict and about the privacy of infected people. In order to make the questions and answers in the questionnaire more understandable, this section is given in table II. The results details are given in Figure 1, Figure 2, Figure 3 and Figure 4. The answers of the students to some questions were detailed examined.

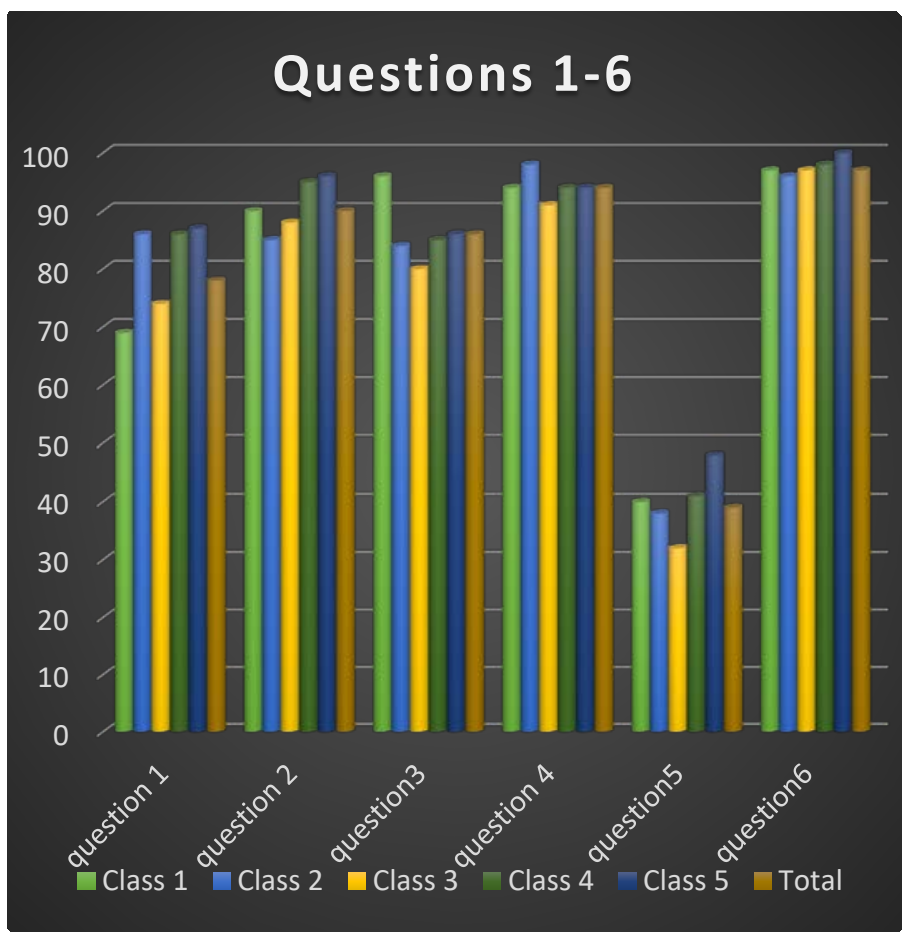

Figure 1. Percentages of questions that measure general knowledge

The correct answer rates for the first 6 questions that measure the general level of knowledge of students in different classes are shown. Question details are given in table I. 


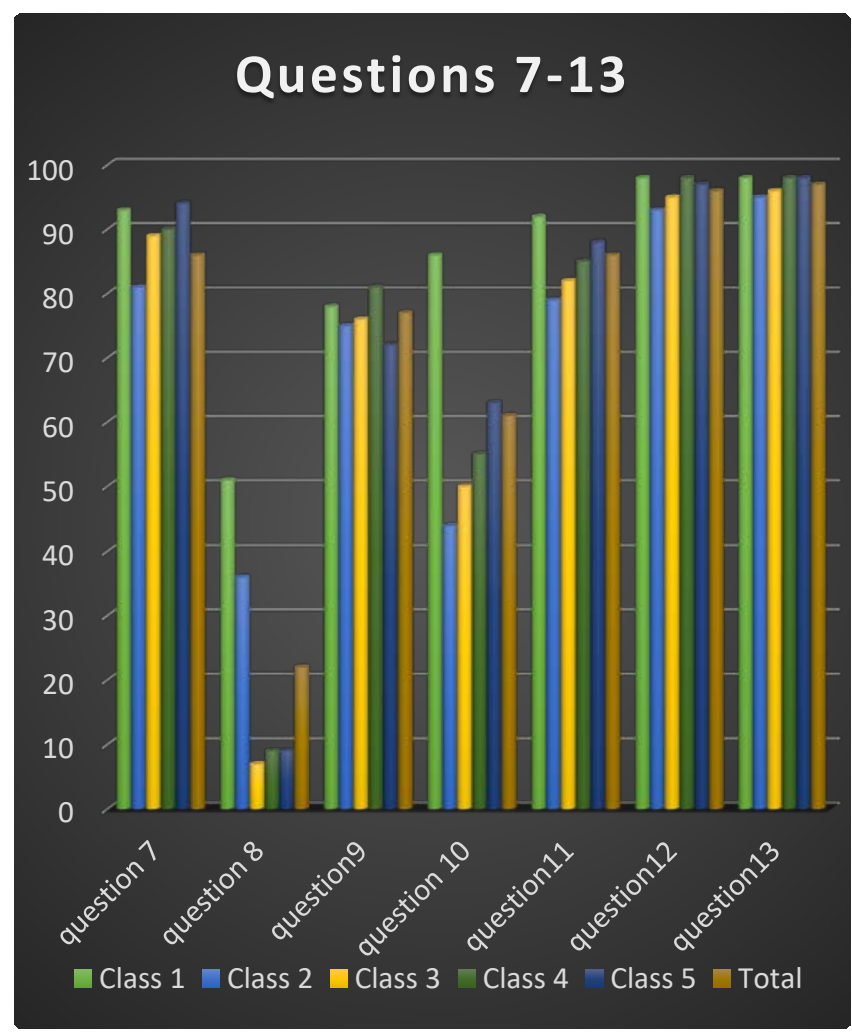

Figure 2. Percentage of response to questions that measure the level of knowledge about transmission routes

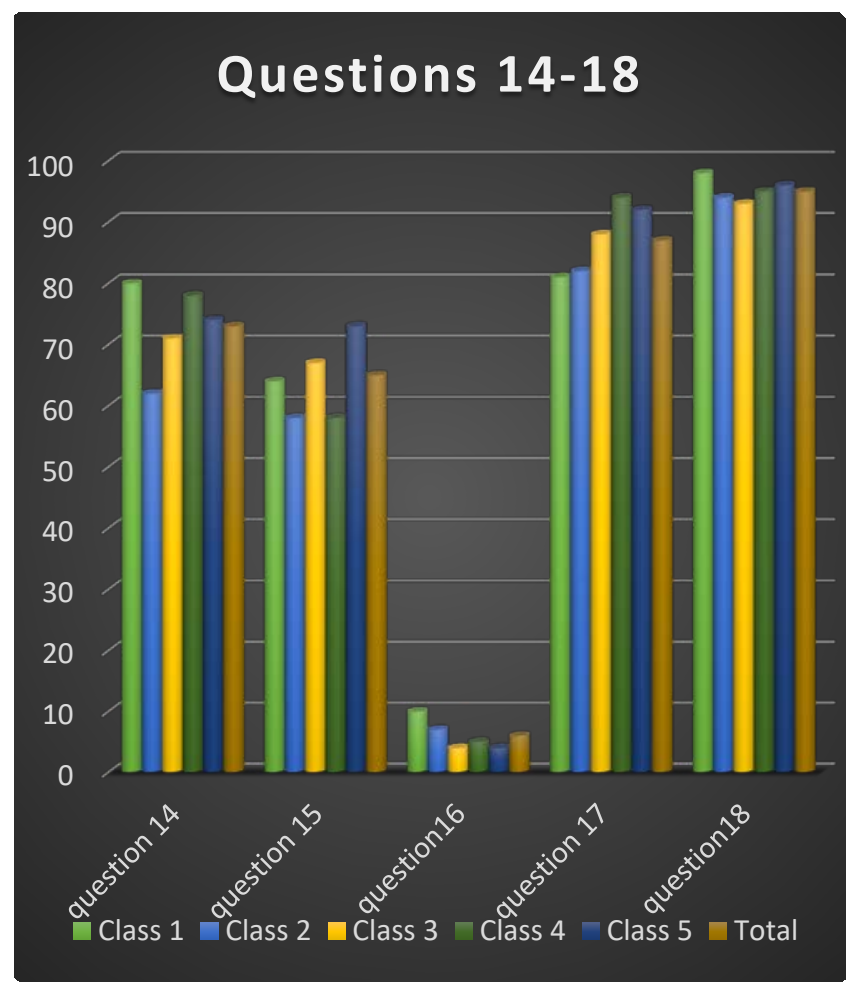

Figure 3. The percentage of response to questions about ways of prevention

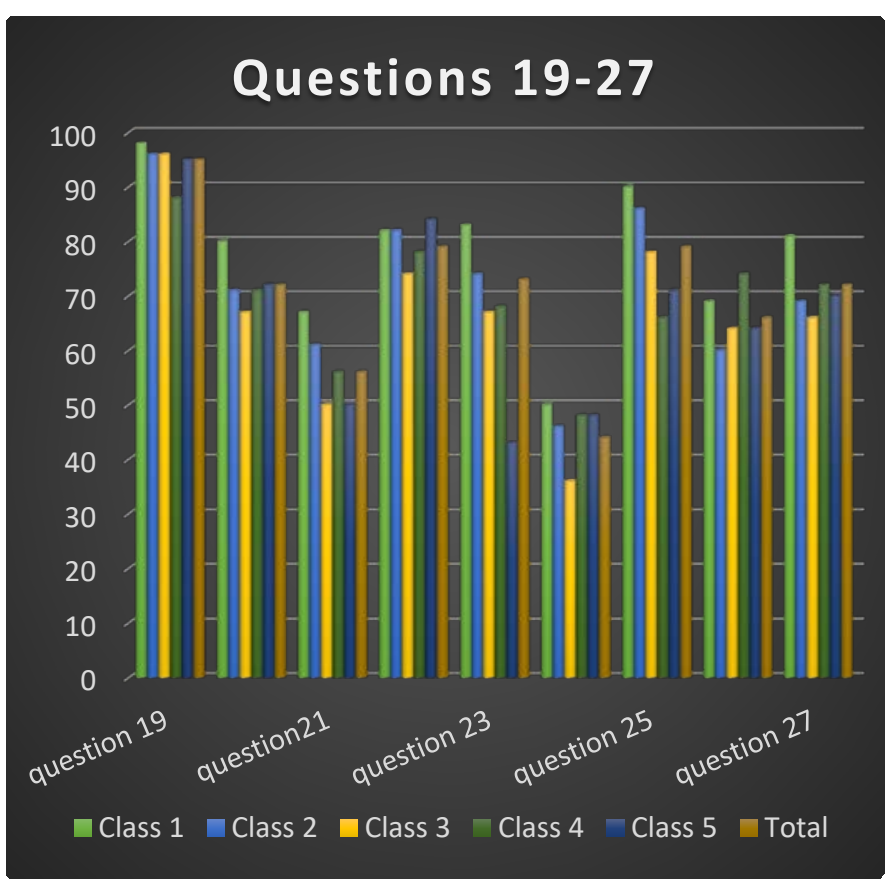

Figure 4. Percentage of answers to questions about attitudes and behaviors

Table I: Demographic characteristics of students

\begin{tabular}{|l|l|l|l|l|}
\hline & Women & Men & $\begin{array}{l}\text { Average } \\
\text { age }\end{array}$ & Total \\
\hline Class 1 & $124(53.4 \%)$ & $108(46.6 \%)$ & $19 \pm 1$ & 232 \\
\hline Class 2 & $77(62.1 \%)$ & $47(37.9 \%)$ & $19 \pm 1$ & 124 \\
\hline Class 3 & $161(53.8 \%)$ & $138(46.2 \%)$ & $21 \pm 1$ & 299 \\
\hline Class 4 & $87(53.7 \%)$ & $75(46.3 \%)$ & $22 \pm 1$ & 162 \\
\hline Class 5 & $81(57 \%)$ & $60(42.3 \%)$ & $23 \pm 1$ & 141 \\
\hline Total & $532(55.4 \%)$ & $428(44.6 \%)$ & $20 \pm 1$ & 960 \\
\hline
\end{tabular}


Table II: Questionnaire questions and answers of students

\begin{tabular}{|c|c|c|c|c|}
\hline & Question & Yes & No & No İdea \\
\hline 1 & An HIV transporter and AIDS patient are the same. & $143(14.9 \%)$ & $751(78.2 \%)^{*}$ & $66(6.9 \%)$ \\
\hline 2 & HIV / AIDS is a viral disease, not genetic. & $866(90.2 \%)^{*}$ & $76(7.9 \%)$ & $18(1.9 \%)$ \\
\hline 3 & There is definitive treatment of HIV / AIDS. & $28(2.9 \%)$ & $826(86 \%)^{*}$ & $106(11 \%)$ \\
\hline 4 & People with AIDS / HIV virus carriers may appear healthy. & $898(93.5 \%)^{*}$ & $31(3.2 \%)$ & $31(3.2 \%)$ \\
\hline 5 & $\begin{array}{l}\text { If you get the appropriate treatment, becoming an HIV carrier is the same as } \\
\text { having a chronic disease like diabetes or hypertension. }\end{array}$ & $372(38.8 \%)^{*}$ & $389(40.5 \%)$ & $199(20.7 \%)$ \\
\hline 6 & HIV is a virus that weakens the immune system. & $935(97.4 \%)^{*}$ & $9(0.9 \%)$ & $15(1.6 \%)$ \\
\hline 7 & AIDS is a sexually transmitted disease. & $77(8 \%)$ & $859(85.9 \%)^{*}$ & $24(2.5 \%)$ \\
\hline 8 & People with homosexual relationships have a higher incidence of HIV / AIDS. & $631(65.7 \%)$ & $211(22 \%)^{*}$ & $118(12.3 \%)$ \\
\hline 9 & An HIV + pregnant woman can get HIV to her unborn baby. & $735(76.6 \%)^{*}$ & $110(11.5 \%)$ & $115(12 \%)$ \\
\hline 10 & An HIV + breastfeeding mother can infect her baby with HIV. & $583(60.7 \%)^{*}$ & $195(20.3 \%)$ & $182(19 \%)$ \\
\hline 11 & $\begin{array}{l}\text { Handshaking with an AIDS patient or sharing personal items (such as teacup, } \\
\text { towels or dress) can cause HIV infection. }\end{array}$ & $82(8.5 \%)$ & $821(85.5 \%)^{*}$ & $57(5.9 \%)$ \\
\hline 12 & $\begin{array}{l}\text { Uncontrolled blood transfusion after HIV + person and forging with the same } \\
\text { tools cause HIV / AIDS infection. }\end{array}$ & $924(96.3 \%)^{*}$ & $13(1.4 \%)$ & $23(2.4 \%)$ \\
\hline 13 & $\begin{array}{l}\text { If } \mathrm{HIV}+\text { a patient-contaminated needle is sinked in a healthy person, there is a } \\
\text { risk of HIV transmission. }\end{array}$ & $930(96.9 \%)^{*}$ & $12(1.3 \%)$ & $18(1.9 \%)$ \\
\hline 14 & One way to prevent HIV / AIDS is to be vaccinated. & $104(10.8 \%)$ & $703(73.2 \%)^{*}$ & $153(15.9 \%)$ \\
\hline 15 & $\begin{array}{l}\text { The only way to prevent HIV / AIDS in sexual intercourse is to use monogamy } \\
\text { and condom. }\end{array}$ & $254(26.5 \%)$ & $620(64.6 \%)^{*}$ & $86(9 \%)$ \\
\hline 16 & Condom use protects against sexually transmitted HIV. & $58(6 \%)^{*}$ & $789(82.2 \%)$ & $113(11.8 \%)$ \\
\hline 17 & Health workers are in a high risk group for HIV / AIDS. & $835(87 \%)^{*}$ & $69(7.2 \%)$ & $56(5.8 \%)$ \\
\hline 18 & Use of protective equipment by healthcare workers reduces HIV transmission. & $913(95.1 \%)^{*}$ & $16(1.7 \%)$ & $31(3.2 \%)$ \\
\hline 19 & The health worker has the right to know the patient's HIV / AIDS status. & $911(94.9 \%)^{*}$ & $28(2.9 \%)$ & $21(2.2 \%)$ \\
\hline 20 & I avoid the follow-up and treatment of HIV / AIDS + patients. & $124(12.9 \%)$ & $691(72 \%)^{*}$ & $145(15.1 \%)$ \\
\hline 21 & I do not want to perform the operation of an HIV / AIDS positive patient. & $211(22 \%)$ & $541(56.4 \%)^{*}$ & $208(21.7 \%)$ \\
\hline 22 & $\begin{array}{l}\text { It annoys me that people around me know that I'm following HIV / AIDS + } \\
\text { patients. }\end{array}$ & $123(12.8 \%)$ & $759(79.1 \%)^{*}$ & $78(8.1 \%)$ \\
\hline 23 & $\begin{array}{l}\text { It annoys me that people around me know that I'm following HIV / AIDS + } \\
\text { patients. }\end{array}$ & $144(15 \%)$ & $700(72.9 \%)^{*}$ & $116(12.1 \%)$ \\
\hline 24 & $\begin{array}{l}\text { HIV/AIDS+ people must be treated in different health care institute and/or in } \\
\text { different units. }\end{array}$ & $401(41.8 \%)$ & $425(44.3 \%)^{*}$ & $134(14 \%)$ \\
\hline 25 & Families of HIV / AIDS + persons should be informed of the situation. & $111(11.6 \%)$ & $756(78.8 \%)^{*}$ & $93(9.7 \%)$ \\
\hline 26 & The HIV / AIDS test cannot be performed without the patient's knowledge. & $637(66.4 \%)^{*}$ & $189(19.7 \%)$ & $134(14 \%)$ \\
\hline 27 & I have problems if I discriminate against HIV/AIDS + patients. & $686(71.5 \%)^{*}$ & $113(11.8 \%)$ & $161(16.8 \%)$ \\
\hline
\end{tabular}

${ }^{*}$ The correct answers are marked with an asterisk (questions 1-18). Instead of determining the correct answer regarding ethical issues, we marked the answers of the majority with an asterisk. 


\section{DISCUSSION}

With increasing rates, HIV / AIDS is an important health problem affecting the whole world. Research has shown that young people are vulnerable to HIV / AIDS. Today, HIV / AIDS has no radical treatment, educating young people to combat this disease is an effective method. HIV cases reported in Turkey in 2012 was observed to be increased in 2016 up to 2.5 folds. It is also noteworthy that the age range of the cases varies between 20-24 years of age9. HIV education can not only help students develop and sustain safer behaviors but will also reduce stigmatization and discrimination towards people living with HIV17. It was thought that the students of the medical faculty who were selected as the study universe would be useful for informing the young population and improving their approaches to the patients ${ }^{18}$.

When the answers of the students to the questionnaires were evaluated, it was seen that their general knowledge level about HIV / AIDS was high (table II). However, some questions and students' answers were found worthy of discussion. The students gave a low response rate $(38 \%)$ to the question: "If you get the appropriate treatment, becoming an HIV carrier is the same as having a chronic disease like diabetes or hypertension" We noticed that this problem was not sufficiently understandable. Because "There is definitive treatment of HIV / AIDS." for question $86 \%$ of the students have answered correctly by saying no. There isn't radical treatment of AIDS today. However, quality of life and duration of the patient can be increased with various antiviral drugs ${ }^{3,12}$.

The correct answer rate of the students was quite high in the questions about the ways of transmission. "People with homosexual relationships have a higher incidence of HIV / AIDS." the question surprised the students. $65.7 \%$ of the students said yes to this question. When the studies in the literature are examined, it is reported that this sexually transmitted disease is more common among heterosexuals than in homosexuals in recent years ${ }^{7}$.

The answers to the questions about the ways of protection were important to us and the students had a high percentage of correct answers. The answer to the question of condom use, which is the most important way of protection in sexual transmission, was interesting. "Condom use protects against sexually transmitted HIV" the question $82.2 \%$ of students answered wrongly. When health professionals are used properly; have reported that condoms prevent sexual transmission of HIV17. This question may have been misunderstood by the students or sexual problems in the middle east region are not explicitly spoken or sexual life outside marriage is less than in other societies, perhaps this, may have affected the response to the question. Therefore, this issue was pointed out in the training seminar.

HIV / AIDS is the disease in which ethical principles are most discussed. Although society has different ideas, the rights of people with HIV / AIDS are guaranteed by law ${ }^{4,19}$. In this context, the students' answers about attitudes and behaviors were important for us. $72 \%$ of the doctor candidates stated that they would not avoid the treatment and follow-up of HIV / AIDS patients. This is a very promising response. The question "I do not want to perform the operation of an HIV / AIDS positive patient." $56.4 \%$ of the students gave a positive answer by saying no. Physician and physician candidates may not want to perform surgical of HIVinfected persons due to the risk of transmission. Ethical debates are continuing, but if infection control methods are provided, doctor candidates have informed that they can perform surgery safely. Thereby, physician candidates were encouraged to treat patients with HIV / AIDS. 
Doctor candidates were again unsure of ethical issues, they alleged that "HIV / AIDS patients should be treated in different health institutions and/or different units." However, legal rules prohibit the isolation of people with HIV / AIDS from society. The principle of respect for the autonomy of the individual protects the rights of persons in their workplaces, health institutions and other public institutions. The freedom of life of individuals like treatment and work cannot be restricted by others ${ }^{20}$.

Should the family of HIV / AIDS patients be informed? The answer to the question is clearer in recent years. The privacy of patients cannot be violated. However, if the patient does not want to explain the situation his or her sexual partner and if a healthy person is at risk of infection, the doctor may inform the patient's sexual partner for protection. The doctor candidates knew that confidentiality was important and $78.8 \%$ responded correctly ${ }^{19}$. In an article published in 2008, Li and colleagues report to a patient's partner that the statement made by the doctor caused the life of the partner21. We talked about the results of informing the family in educational seminars. Because the legislation is not sufficiently clear on this issue in Turkey.

\section{CONCLUSIONS}

UNESCO prepared a new educational guide on World AIDS Day. Today the world is trying to stop HIV / AIDS cases by 2030. He realized that one of the most important methods for this was the training of young people. In our study, we measured the HIV / AIDS knowledge level of 960 medical school students, the results were not bad but were not sufficient for us. For this reason, a training seminar was given by the academicians of the Department of Infectious Diseases and Infectious Diseases of Atatürk University Faculty of Medicine on December 1, 2019 World AIDS Day. The questions that students answered incorrectly were pointed out. Prospective physicians now report that they trust them more about HIV / AIDS. We think that training seminars should be expanded and more young people should be reached. Sufficient time should be spent for HIV / AIDS and young people should be reminded with brief educations.

Ethics Committee Approval: The study initiation, ethical approval was obtained from the ethical board of the university where the study was conducted. The research protocol was approved by the Atatürk University Medical Faculty research ethics committee before the study (Ethics Committee Approval Number: B.30.2.ATA.0.01.00/314).

Declaration of Conflicting Interest: The authors declare no conflict of interest.

Financial Disclosure: The authors declare no financial support for this study.

\section{REFERENCES}

1. Lazar DC, Morris KV, Saayman SM. The emerging role of long non-coding RNAs in HIV infection. Virus Res. 2016; 212: 114-26.

2. Verulava TKI, Abulashvili S. Students' awareness, knowledge, and behavior regarding HIV/AIDS. Gazi Med J. 2018; 29: 215-18.

3. Aslan FG, Altındiş M. current diagnostic algorithm of HIV and emerging prevention methods. Turk Mikrobiyol Cemiy Derg. 2017; 47: 47-60.

4. Jarvis M, Beall J, Woolley T. Knowledge and attitudes of pharmacy students towards human immunodeficiency virus (HIV). Curr Pharm Teach Learn. 2015; 7: 137-40.

5. O'Cofaigh E, Lewthwaite P. Natural history of HIV and AIDS. Medicine. 2013 ;41(8): 411-16.

6. World Health Organization (WHO) Data and statistics 2020, Global Health Observatory (GHO) data, Available from: https://www.who.int/data/gho/data/themes/hivaids Accessed: 20 October 2020.

7. Melhuish A, Lewthwaite P. Natural history of HIV and AIDS. Medicine. 2018; 46: 356-61. 
8. Gülümser Ç, Erbaydar T. HIV/AIDS epidemic in Turkey and use of antiretroviral drugs for treating pregnant women and preventing HIV infection in infants. Turk J Obstet Gynecol. 2015; 12: 192-8.

9. Gökengin D. HIV infection in Turkey: How close are we to the target? Klimik Derg. 2018; 31: 4-10.

10. Savaşçı Ü, Avcı IYY. Infectious Agents Transmitted by Blood and Blood Component and Impacts of Nükleik Asit Amplifikasyon Test (NAT). IKSSTD, 2016; 8: 125-34.

11. Akgul Ö, Çalışkan R, Öner YA. HIV/AIDS: Current Perspectives. TFK. 2018; 1: 19-31.

12. Solmaz Avcıkurt A. Evoluation of Knowledge and Attitudes on HIV/AIDS of Balikesir Universty Student. Balıkesir Sağlık Bil Derg. 2014; 3: 79-86.

13. Ghosn J, Taiwo B, Seedat S, et al. HIV. The Lancet. 2018; 392 (10148): 685-97.

14. Doda A, Negi G, Gaur DS, Harsh M. Human Immunodeficiency Virus/Acquired Immune Deficiency Syndrome: A survey on the knowledge, attitude, and practice among medical professionals at a tertiary health-care institution in Uttarakhand, India. Asian J Transfus Sci. 2018; 12: 21-6.

15. Castle C. UNESCO Institute, [Internet]. UNESCO Institute, Young people have a right to education that will be useful for their lives, not just literacy and mathematics; 2018. [updated 2018 Apr 18; cited 2020 Sept 26]. Available from: https://iite.unesco.org/news/chris-castle-hivinterview/
16. Mani SB, Bral DO, Soltanianzadeh Y, et al. Evaluating Attitudes Toward and Knowledge of Human Immunodeficiency Virus and Sexually Transmitted Infections in First-Year Medical Students, J Stud Run Clin. 2018; 4: 1-7.

17. UNAIDS [Internet]. 2014 Education and HIV: where we've come from and where we need to go [updated 2014 Apr 1; cited 2020 Sept 26]. Available from:

https://www.unaids.org/en/resources/presscentr e/featurestories/2014/april/20140401unesco

18. Hoşoğlu S, Bozkurt F, Tekin R, et al. Impact of an educational meeting on knowledge and awareness of general practitioners on upper respiratory tract infections. Dicle Med J. 2012; 39: 157-61.

19. Haire B, Kaldor J. HIV transmission law in the age of treatment-as-prevention. J Med Ethics. 2015; 41: 982-86.

20. McMillan JR, Conlon C. The Ethics of Research Related to Health Care in Developing Countries. J Med Ethics. 2004; 30: 204-6.

21. Li L, Lin C, Wu Z, et al. To tell or not to tell: HIV disclosure to family members in China. Dev World Bioeth. 2008; 8: 235-41. 